\title{
Developing Marketing and Advertising Strategies Through Disruption Philosophy
}

\author{
N. Delener \\ School of Business and Economics, Indiana University East \\ 2325 Chester Blvd., Richmond, IN 47374, U.S.A.
}

\begin{abstract}
Disruption is about finding the strategic idea, which breaks and overturns a convention in the marketplace, and then makes it possible to reach a new vision or to give new substance to an existing vision. A business strategy revolves around three basic constructs, namely, vision, core values and a business typology. When an organization must drastically change two of the three basic constructs in order to survive, it has been strategically disrupted. These basic constructs represent how the upper management of a business envision the future, how they are guided by their core values to benefit from that vision, and how they would organize the business to maintain these benefits. When the magnitude of change that causes strategic disruption is significant, it is literally a make or break experience for that business or organization. A proactive strategy can help a company to overcome significant disruption. Therefore, this paper explores how disruption philosophy affects strategic marketing and advertising decision-making process.
\end{abstract}

Keywords: Marketing Strategy, Advertising, Business Strategy, Disruption Philosophy, Branding

DOI: $10.7176 / \mathrm{JMCR} / 54-05$

Publication date:March $31^{\text {st }} 2019$

\subsection{Introduction}

The management of brands as assets is certainly more complex and more powerful today and find no one is better equipped to help in this area than marketing and advertising strategists. But they too must give up their conventions (i.e., Aaker, 2014; Bagga, Noseworthy \& Dawar, 2016; Dawar, 2018). They need more than intuition and imagination. They need and have developed a new discipline called Disruption. Disruption is discontinuous thinking applied to the task of marketing and advertising. It means that marketing and advertising managers are no longer in the business of simply making decisions. Rather, their job is to create or improve on their brands that will disrupt the marketplace in their favor.

Disruption means identifying, questioning and overturning the conventions that define an existing marketing situation. Such conventions exist everywhere - no matter what the brand, category or marketplace - but they are usually hidden. Conventions are the unquestioned assumptions, the common-sense wisdom, the current rules of game that comprise the status quo it-one's marketplace. Marketing and advertising managers' job with disruption is to uncover these conventions, question their validity. For example, it is conventional thinking to target pet food advertising to adults, not kids. Quaker has questioned this in Europe by building its strategy on the relationship between pets and kids. By challenging established conventions, disruption is the springboard to vision. Hamel and Pralahad (1991 \& 1994) state that "having the imagination to envision markets that do not yet exist and the ability to stake them out ahead of the competition". Several authors are blunter: If you try to redefine an industry, you will probably fail. If you don't try, you will fail (Green, 2018; Porter, 2016). Therefore, this article aims to explore how disruption philosophy affects strategic marketing and advertising decision making process.

\subsection{Why Disruption Philosophy is Important \\ 2.1 Markets Have Changed}

Innovative companies have discovered that it is not enough to follow customer needs - they must lead them (Kotler \& Keller, 2016). At the end of the 1990's and beginning of the 2000's, a lot of companies, which more and more often are facing tough foreign competition, understand that they must create new competitive space or reshape the existing space. According to several authors, companies must stretch their corporate imagination (Bonchek \& France, 2017; Mintzberg, Lampel \& Ahlstrand, 2005; Papandrea, 2016). Meanwhile advertising agencies produce more of the same. That is why, as an industry, advertising has lost the magic. Advertising does not lead the market anymore. Today it seems as if it cannot even follow. Advertising managers think and behave in a very conservative way. They are no longer anti-conformists. This must be changed. Disruption is the advertising translation of the evolution in the industrial sector. Change used to mean the same, only better. But not anymore. Change is no longer a linear process, a continuous pattern. Change is discontinuity. Change requires discontinuous thinking.

\subsection{The Old Logic Does Not Work Anymore}

Advertisers are gradually losing their potent advantage as the repository of information about the consumer, the 
media or the society. Advertisers could become nothing more than executors of someone else's ideas. .The advertising industry's only real change to survive is to move from this "knowledge position" to a new mind set. This new mind set is total commitment to marketplace disruption.

To disrupt means to reframe, to reshape, to restage. To take information, perspective, knowledge and look at them from a new light. The disruption will materialize through a leap, a turning point, a transversal idea, you name it. It will reframe the familiar scene, it will re-conceptualize the obvious. Reframing is the ability to see things, problems, situations, or people in other ways; to put them in another perspective or another context. In doing so, marketing and advertising managers will create new visions for their products and brands.

\subsection{Consumers Passivity Needs to Be Confronted}

Consumers have less time and less financial resources these days to make mistakes, and this means less trial. So what marketers interpret as consumers' loyalty to brands is often nothing more than mere passivity. In this kind of marketplace, brands, at best, maintain share, or vie with promotions and pricing to attract new consumers who, by definition, will not be loyal. If marketers and advertisers want their brands to grow, and grow profitably, then something must intrude on consumers' thoughts, feelings and behaviors. They must disrupt these ordinary, comfortable patterns of "non-choice" -- this inclination toward disinclination.

\subsection{The Disruption Process}

Inspiration, talent and luck are important when developing the disruptive approach, but practice plays the leading role. One must understand the conventions before having the right and the ability to challenge them and then the disruption created must be linked to a vision. This is the disruption process. A simple paradigm (Figure 1) shows the steps in the disruption process. Disruption thinking is not a step-by-step process which should always be tacked in the same order. The four steps can be used in a different order according to necessity. There must be no preconceived idea on the process. In many cases, it is the vision that leads to the idea for a disruption. In other cases, however, it is the disruption idea that leads to or even inspires the vision. There is therefore no hard and fast rule and the process is totally flexible from this point of view.

Figure 1:Disruption Process

\begin{tabular}{|l|c|}
\hline Step 1 & Understanding the convention \\
& [Credibility] \\
\hline Step 2 & Challenging the conventions \\
& [Insight] \\
\hline Step 3 & Creating a disruption \\
Step 4 & Establishing a vision \\
& [Discipline] \\
\hline
\end{tabular}

\section{Step 1: Understanding the Conventions}

The broadest definition of a convention is a generally accepted idea which influences people's perceptions of their environment. All conventions are based on a certain degree of reality, facts, objects, behavior, and experience. But it is the general perception of the reality which determines the conventions. As several researchers stated, perception matters more than reality (Mothersbaugh, 2018; Schiffman \& Wisenblit, 2019; Zealley, Wollan \& Bellin, 2018).

Marketing strategy conventions are directly derived from the marketing thinking of the firm. They refer to the offer (what to sell), the target (who to sell it to), or the competition (who are the competitors). An offer convention is related to what an industry generally considers to be the most attractive offer for the consumers, and the one which every company in the sector will try and prove it can deliver better than its competitors. An offer convention in retailing is: the only way to succeed in retailing is to offer the best combination of price, choice and service.

A convention on the target reflects a generally accepted idea by a firm about a consumer group. Many companies think in such a way as "our products and/or services are only appreciated by a certain consumer category", or "you will never sell such a product/service to such and such a consumer group." Specific examples are: only women buy skin-care products, or you can not sell snack crisps to adults.

A convention on competition is related to the idea firms have about their competition. The conventions most likely to interest us in this case are those which result in a very narrow conception of the competition, either by underestimation of the possible vertical 'integrations in the sector (e.g., the development of distributors' brands), or by ignorance of substitute products; e.g., Netflix first distributed Blockbuster and then broadcast networks and cable companies by re-imaging how we consume tv shows and movies.

\section{Step 2: Challenging the Conventions}

There are three techniques strategist can use in challenging the conventions.

They are intended as ways to think and places to look for inspiration. 
- The 'What If Process" is a set of proprietary questions about the conventions that are typical of a wide variety of marketing situations. Precisely because these are questions about conventions, they are highly likely to reveal opportunities for disruption.

- The Cross-Cultural Analyses are cross-national analyses of some categories of marketing and advertising that identify culture-based conventions and offer culture-driven disruptions.

- The Disruption Worldbank is a collection of disruption case studies from around the world. Each case study follows a similar format in which the marketing challenge, the disruption, the creative solution and the results are identified.

\section{Step 3: Creating Disruption}

Disruption is about finding the strategic idea which breaks and overturns a convention in the marketplace, and then makes it possible to reach a new vision or to give new substance to an existing vision. Creating advertising strategy involves the product/service, the consumer and advertising agency. Three different worlds and hence three different sources of inspiration for disruption. Indeed, a great majority of disruption strategies stem from a new marketing idea, a new consumer insight or a new advertising focus,

Marketing Idea: We are talking about an idea inspired by an insightful observation of product? service or marketing strategy. It has to be innovative and result in something tangible and concrete. It may even lead to the extension of a product line or service. For example, the idea of changing the logic of marketing strategy components:

- Adopting a new advertising expenditure allocation strategy for Danone to reinforce the brand's commitment to health through a corporate campaign on top of product advertising.

Consumer Insight: Inspiration may come from an intrusive look at the consumer's way of thinking, feeling or acting. Advertising is most persuasive when it is based on a special key insight into current consumer beliefs or practices related to a category or product. A consumer insight leads to a disruption when:

1. It has not yet been exploited by the competition.

$>$ You have to grow old gracefully is our entrenched attitude. Understanding that, in fact, no woman can accept growing old and expressing it for the first time is the Disruption way (Oil of Olay).

2. Or it is an innovative way of focusing on a use or attitude that changes the consumer's perspective of the, product/service.

$>$ Amplifying Polaroid's functional use as a visual memo because a "picture is worth a thousand words" led to a reevaluation of Instant Photography.:

Advertising Focus: The third source of disruption consists of modifying the focus of the advertising proposition. This focus can be one of the following (see Figure2):

\section{Figure 2: Functions of Advertising}

$>$ Reinforce top-of-the-mind awareness

$>$ Highlight an attribute

$>$ Emphasize a benefit

$>$ Establish a territory

$>$ Reflect a value

$>$ Claim a role.

To move up and down this ladder will change the advertising focus and hence create a disruption.

\section{Step 4: Establishing a Vision.}

A vision is a picture of where the product, service or company will be over time. It is a leap from where we are now to a larger, more ambitious scale. Its role is to expand the possibilities, to clarify strategic direction, to unify the brand franchise, to define the largest possible target. A vision naturally aligns everyone on the brand, and guides all activities: product development, promotion, packaging, market research and so forth, beyond mere advertising.

We consult the vision when we are at a crossroads to make sure we are remaining "true" to it. We defer to it when impulse distracts us. We derive inspiration from it when we are looking for future direction. We refer to it when we establish our priorities. In other words, the vision keeps us honest and focused - the vision keeps us moving forward, and in a consistent direction.

A vision is not only a mission or a positioning, although it is akin to the two concepts. Mission is commonly used to explain the business a company is in, or wants to be in. Specifically, a mission is exclusively inwardlooking. For example, Google defined its mission as to organize the world's information and make it universally accessible and useful. As such, the term mission has meaning largely internally, to the company itself. Positioning is commonly used to mean what a product or service stands for in the minds of its target audience. In other words, positioning is exclusively outward looking. For example, Apple is positioned as the great product and holding on high standards of quality.

A great vision is the perfect fusion of what a company, product or service could possibly stand for and what 
the ultimate consumer really needs. To achieve it requires homework, especially on two fronts: [a] Analyze the company, product, service's "core competencies", product history, company policy, expertise and values. [b] Identify changes in consumer needs and aspirations. The convergence of both perspectives leads to a vision.

\subsection{Preparing the Disruption Format}

The order in which convention, disruption and vision are presented must reflect the logic of your thinking. This is essential since it will affect the understanding of its main users: the creative strategic people. This disruption document accompanies the creative brief, and at the same time provides its necessary strategic perspective. However, it does not constitute the entire brief itself: the definition of the target, the competition, the message or the desired response from the consumer all figure on your classic internal brief document. Still, the selected advertising or marketing proposition which is in fact the core of the message, will be part of the disruption format and mentioned at the bottom of it. It concludes the thinking and provides a useful focus for the creative brief. Some advice when writing the disruption format is presented in Figures 3A \& $3 \mathrm{~B}$ ).

Figure 3 A: Writing the Disruption Document

\begin{tabular}{|c|c|}
\hline $\begin{array}{l}\text { - Convention is an opinion, an interpretation } \\
\text { market fact. }\end{array}$ & the reality. It should not be written as a consumer or \\
\hline$\underline{\text { A Fact }}$ & An Opinion. \\
\hline $\begin{array}{l}\text { Like all Japanese cars, Lexus is bought on the basis of } \\
\text { strong product attributes: high technology and good } \\
\text { value for money. }\end{array}$ & Buying a Lexus is above all a relational purchase. \\
\hline - Disruption: is a strategic idea. Avoid writin & it as an objective. \\
\hline An Objective & A Strategic Idea \\
\hline $\begin{array}{l}\text { Create the image of the best presenter of music for } \\
\text { Virgin. }\end{array}$ & $\begin{array}{l}\text { Virgin advertising should go far beyond the attributes } \\
\text { and play an actual role as the best presenter of music }\end{array}$ \\
\hline $\begin{array}{l}\text { - Vision is a leap from where we are to wh } \\
\text { statements do not apply. }\end{array}$ & re we ultimately want to be. Promise or positioning \\
\hline A Positioning & A Leap \\
\hline $\begin{array}{l}\text { Mattel, the brand of toys that contributes } \\
\text { to the intellectual development of your children. }\end{array}$ & Mattel is above all a child's educator \\
\hline
\end{tabular}

\section{Figure 3B: Creating Disruption}

\section{How to generate such ideas? Learning from previous successes.}

1. A tangible idea: Innovates market - driven idea that helps to give a new perspective on a product, brand or company, to substantiate a new vision, or to provide a new reason- why to advertising / marketing.

\section{Case: Danone}

Vision: Danone is in the business of health.

- Convention: The conventional rules of marketing thinking go like this: a product- a brand- a benefit - a budget.

- Disruption: Reallocate advertising / marketing funds to create an umbrella campaign whose purpose is to substantiate Danone's stance on health.

New consumers' insights can be obtained through reviewing consumer research, surveying consumer, and adopting the "detective" attitude.

2. How to get a tangible idea

A. Identify opportunities by analyzing the components of the company marketing activities:

brand name, packaging, service, promotion, distribution, pricing, etc.

\section{Case: Kodak Film Company}

Convention: The quality of a film is shown by the end result.

Vision: High definition, a new way of defining superior quality of films.

Disruption: To exploit a product name from another category to convey superiority.

B. A new consumer insight: The idea resulting from an intrusive look at the consumer's way of thinking, feeling or acting that has not yet been discovered by competition.

\section{Case: Mobil}

Convention: Gas stations are all the same.

Disruption: Dare to make a case of this fact.

Vision: Mobil is committed to constantly providing a tangible difference in terms of products and services. A new consumer insight can be obtained through reviewing consumer research, surveying consumer, and adopting the "detective" attitude. 
3. A change in advertising: The idea of shifting the advertising focus from one modality to another.

$>$ Advertising plays very diverse roles:

- Reinforce top of mind awareness.

- Highlight an attribute.

- Emphasize a benefit.

- Establish a territory.

- Reflect a value.

- Claim a role.

$>$ Identity the dominant focus of competitive advertising is the convention.

$>$ Move up, move down the ladder asking "What if" is the disruption. i.e.,

- What if we stake out territory?

- What if we incarnate a value?

- What if we increase the price?

The exception that proves the rule. Focusing on the basic promise of a product, doing generic advertising or promoting a collective benefit are apparently routes that maintain conventions. BUT doing it better than anyone else has done before, in such a way that the brand, product, or company gives the impression of representing the entire category or industry, is a DISRUPTION.

Structure your imagination.

A. Don't jump on the first idea that simply contradicts the convention.

- Disruption is rarely the simple opposite of a convention

- To contradict, to oppose something else to a convention is the objective, no the idea itself.

B. Structure your imagination

- Use the inspirational tools

- The What if process

C. Encapsulate your thinking in precise wording.

- The Disruptive idea will be expressed as an action at the marketing, consumer or advertising level, not as an objective.

\section{Example: Minolta}

* An objective:

o Create the image of the best present of pictures

* A disruptive idea:

o Go far beyond the attributes and champion the causes of picture

D. Change and revise your attitude.

- Resist the obvious, and question, question....

- Behave as a rebel (creative people have always been)

\section{Example: Beer Conventions and Disruptions}
* Drop assumptions; create hypothesis
* Ask what if? Why not?

Marketing:

Convention: "Real" tap beer with a creamy head can only be found in bars.

Disruption: Real tap beer in a can.

Convention: Beer brands should appeal to the widest group of drinkers possible. Advertising:

Disruption: Make the brand elitist by focusing on individualism and intelligence.

Convention: Advertising should associate the beer brand with convivial beer scenes and Social interaction. Consumer:

Disruption: Use a typical brand heritage to create a new advertising territory.

Convention: Beer is about taste.

Disruption: Smoothness is as important as taste.

\subsection{Conclusion}

Disruption is not only a strong discipline for designing strategies, it should also lead to better briefs - and better briefs remain the key factor to maximizing changes to achieve great marketing and advertising. Disruption leads to new angles in the marketing and advertising proposition and ensures that there is already room for change within the brief.

It is true that the most talented creative people can always find a new emotional angle on the most over-used 
promise - such as "good taste"! -- the consumer is more and more marketing or advertising-literate and understands quickly that he/she is being presented with a more-of-the same message. Therefore, if the brief already encapsulates a discontinuity, a disruptive thought, it will involve and liberate creative strategists. They will be motivated by the fact that their creativity is not wasted or betrayed by a banal thinking.

Disruption philosophy should be used in operations and planning of air travel and urban rail transit systems due to the stochastic variations in passenger demand. A strategic plan can be produced to absorb minor disturbances. The design of such a strategic plan that guarantees expected travelling time would be an important future research field.

\section{REFERENCES}

Aaker, D. (2014), Aaker on Branding: 20 Principles That Drive Success. Morgan James and The Entrepreneurial Publisher.

Bagga, C., Noseworthy, T. J. \& Dawar, N. (2016), "Asymmetric Consequences of Radical Innovations on Category Representations of Competing Brands," Journal of Consumer Psychology, January 26(1): 29 - 39.

Bonchek, M. \& France, C. (2017), "What Creativity in Marketing Looks Like Today," Harvard Business Review -Digital Article (March-April): 2-6.

Dawar, N. ( 2018), "Marketing in the Age of Alexa", Harvard Business Review: 80 - 86.

Green, R., Disruption Forum, Inc. 2013-2018.

Hamel, G. \& Pralahad, C.K. (1991), "Corporate Imagination and Expeditionary Marketing," Harvard Business Review (July-August):81-92.

Hamel, G. \& Prahalad, C.K. (1994), “Competing for the Future,” Harvard Business Review (July-August):122129.

Kotler, P. \& Keller, K. L. (2016), Marketing Management, $15^{\text {th }}$ Edition, Pearson.

Mintzberg, H., Lampel, J. \& Ahlstrand, B. (2005), Strategy Safari: A Guided Tour Through the Wilds of Strategic Management. Free Press.

Mothersbaugh, D. (2018), Consumer Behavior: Building Marketing Strategy, $13^{\text {th }}$ Edition McGraw Hill.

Papandrea, D. (2016), "How to Connect with a Hard-to-Reach Audience: A Niche Marketing Strategy," Content Marketing Institute, August 28.

Porter, M. E. (1990), “The Competitive Advantage of Nations,” Harvard Business Review (March-April): 73-93. Schiffman, L., G. and Wisenblit, J. L. (2019), Consumer Behavior, $12^{\text {th }}$ Edition, Pearson.

Zealley, J., Wollan, R. \& Bellin, J. (2018), "Marketers Need to Stop Focusing on Loyalty and Start Thinking About Relevance," Harvard Business Review (March-April):2-7. 